\title{
CHARACTERIZATION OF ANTIBODIES IN NORMAL HUMAN URINE*
}

\author{
By EZIO MERLER, $\dagger$ JACK S. REMINGTON, $\ddagger$ MAXWELL FINLAND, AND \\ DAVID GITLIN WITH THE TECHNICAL ASSISTANCE OF CORNELIA PROCTOR \\ (From the Departments of Pediatrics, Biochemistry, and Medicine, Harvard Medical School, \\ and the Thorndike Memorial Laboratory, Second and Fourth [Harvard] Medical \\ Services, Boston City Hospital, Boston, Mass.)
}

(Submitted for publication November 6, 1962; accepted May 2, 1963)

Certain of the physiochemical and immunochemical properties of the $\gamma$-globulins of normal human urine have been reported by Webb, Rose, and Sehon (2) and by Franklin (3). These urinary proteins were found to be electrophoretically and antigenically closely related to serum $\gamma$-globulins, but smaller in size; their molecular weights ranged from 10,600 (2) to 38,000 (3). Sedimentation coefficients $S_{w, 20}$ for the major constituents of the urinary $\gamma$-globulins were reported to be $1.14 \mathrm{~S}(2)$ and $1.6 \mathrm{~S}(3)$. Although Webb and associates (2) and, more recently, Rowe and Soothill (4) did not demonstrate $7 \mathrm{~S}$ material in total urine concentrates, Franklin (3) noted a small amount of a rapidly sedimenting component with $S_{w, 20}$ of about 7 , in addition to the major 1.5 to $1.6 \mathrm{~S}$ peak in $\gamma$-globulins from a number of different urines.

Recently, precipitating and viral neutralizing antibodies were shown to be present in the $\gamma$-globulins of normal human urine $(5,6)$. The antibody activity was considered to be probably residing in the $7 \mathrm{~S}$ fraction. Porter (7), has shown however, that nonprecipitating fragments with an approximate molecular weight of 55,000 , obtained by enzymatic degradation in vitro of rabbit serum antibodies, retain the ability to combine specifically with homologous antigen. The present studies were therefore undertaken to determine whether the low-molecular-weight $\gamma$-globulins of normal urine possess antibody activity, and preliminary observations (8) suggested that they do.

* Presented in part before The Federation of American Societies for Experimental Biology on April 14, 1962 (1). Aided by grants A-251 and E-23 from the National Institutes of Health, Bethesda, Md.

$\nmid$ Present address: Palo Alto Medical Research Foundation, Palo Alto, Calif.

$\ddagger$ Postdoctoral Research Fellow, National Institutes of Health.

\section{METHODS}

Collection and treatment of urine. Urine was collected in clean containers without preservative. The following procedures were employed to concentrate the urine. 1) Lyophilization. After filtration through Whatman 12 filter paper, the urine was dialyzed through 18/32-inch Visking 1 tubing against either distilled water or running tap water at $10^{\circ} \mathrm{C}$ for 48 to 72 hours and lyophilized. 2) Pervaporation followed by lyophilization. After filtration and dialysis, urine was poured into a reservoir connected to twelve 6-foot columns of 8/32-inch Visking tubing, which presented a large surface area per unit volume. The lower ends of the tubing were immersed in running tap water at $10^{\circ} \mathrm{C}$ while the upper portions were exposed to three table fans. From 5 to $10 \mathrm{~L}$ of urine could thus be concentrated 100-times in less than 8 hours. The concentrated urine, usually dark brown in color, was then lyophilized. Sufficient $0.15 \mathrm{M} \mathrm{NaCl}$ was added to bring the powder into solution; this was centrifuged at $3,000 \mathrm{rpm}$ for 30 minutes, and the supernatant fluid was stored at $-20^{\circ}$ C. 3) Passage through Sepha$d e x .^{2}$ The method used was a modification of the procedure described by Flodin, Gelotte, and Porath (9). After filtration through Whatman 12 filter paper, the urine was added to Sephadex G-25. The thick suspension was thoroughly stirred, allowed to stand at room temperature for 15 to 30 minutes, and then filtered with suction through Büchner funnels with interposed finemesh metal screen (10). The efficiency of this filtration was further enhanced by a sheet of rubber or Parafilm ${ }^{3}$ placed over the top of the funnels. Filtrates were then reconcentrated in the same manner to about 1/500th to $1 / 1,000$ th of the original volume of urine; 2 to $3 \mathrm{~L}$ of the original urine was thus reduced in 3 or 4 steps to 1 to $3 \mathrm{ml}$.

$7 S \gamma$-globulin. Human $\gamma$-globulin was obtained from pooled plasma of normal adults by low-temperature ethanol-water fractionation (Squibb lot 330-2). Approximately $96 \%$ of this material settled as sediment in the ultracentrifuge with an $S_{w, 20}$ of 6.8 at a protein concentration of $1 \%$. Less than $4 \%$ of molecules settled as sediment at 9 to $11 \mathrm{~S}$, and no detectable amount did so

1 Visking Co., Division of Union Carbide Corp., Chicago, Ill.

2 Pharmacia, Uppsala, Sweden.

${ }^{3}$ Marathon Co., Menasha, Wis. 
at $19 \mathrm{~S}$. The material had the electrophoretic mobility of normal human $\gamma$-globulin and gave a single precipitin line upon immunoelectrophoresis with an antiserum to normal human serum.

Antisera. A pool was made of sera obtained from 4 rabbits immunized with human serum $7 \mathrm{~S} \boldsymbol{\gamma}_{2}$-globulins. Antiserum 4 13,411 from a horse immunized with whole normal human serum was used.

Immunoelectrophoresis. The micromethod of Scheidegger (11) was employed, with $1 \%$ agar in borate buffer at $\mathrm{pH} 8.6(\mu$ 0.064). The precipitin lines appeared to be at optimal intensity after 24 to 72 hours. The agar was washed in $0.15 \mathrm{M} \mathrm{NaCl}$; the precipitin lines were stained with Nigrosin or Ponceau S.

Double diffusion in agar gel. The technique of Ouchterlony (12) was used. In some instances, double diffusion in tubes was used as described by Preer (13). Quantitative estimation of urinary $\gamma$-globulins was performed as described by Feinberg (14).

Immunization. Two persons with normal blood urea nitrogen and urine that was free of protein by the sulfosalicylic acid test were given booster doses of tetanus toxoid. Ten days later a serum sample was drawn; collection of total urine output was then begun and continued for 10 days in one subject and for 14 days in the other.

Volunteers immunized with poliovirus vaccine were the same as those used previously (Subjects 1 and 5) (6).

Chromatography. Fractionation of the urinary proteins was performed on columns of DEAE cellulose ${ }^{5}$ at room temperature. All buffer solutions were saturated with toluene. Concentrated urine was dialyzed against 0.0175 $\mathrm{M}$ phosphate buffer at $\mathrm{pH} 6.3$, and insoluble residues were removed by centrifugation at $2,000 \mathrm{rpm}$ for 20 minutes. The clear, dark, supernatant fluid was placed on the column previously equilibrated with starting buffer until the effluent had a $\mathrm{pH}$ of 6.3 .

Columns were connected to a continuous-flow ultraviolet absorption meter, and the optical density of the eluates at $254 \mathrm{~m} \mu$ was recorded directly. Elution with $0.0175 \mathrm{M}$ phosphate buffer at $\mathrm{pH} 6.3$ was continued until there was no further ultraviolet absorption. A linear gradient (phosphate, $0.0175 \mathrm{M}$ at $\mathrm{pH} 6.3$ to $0.4 \mathrm{M}$ at $\mathrm{pH}$ 5.2) was then used to separate the remaining urinary proteins.

Contents of tubes comprising portions of the elution patterns within each peak were combined, dialyzed against distilled water, and lyophilized. After the addition of 1 or $2 \mathrm{ml}$ of $0.15 \mathrm{M} \mathrm{NaCl}$ to each lyophilized fraction, small amounts of insoluble cellulose resin were separated by centrifugation at $15,000 \mathrm{rpm}$ for 20 minutes.

Enzymatic digestion and peptide patterns. Proteins were denatured before enzymatic digestion either by heating at $\mathrm{pH} 8$ for 45 minutes at $100^{\circ} \mathrm{C}$, or by oxidation with performic acid (15). Enzymatic hydrolyses were performed in the $\mathrm{pH}$-stat at $37^{\circ} \mathrm{C}(16)$. Twice-crystallized $\operatorname{tryp}^{6} \sin ^{6}$ was used in a 1:20 enzyme:substrate ratio.

4 No. 13,411, Institut Pasteur, Paris, France.

5 Selectacel 70 Standard grade, Brown Co., Berlin, N. H.

6 Worthington Biochemical Company, Freehold, N. J.
The peptides obtained from each digestion were separated on paper in two dimensions, first by electrophoresis in one direction, followed by ascending chromatography in the second, as described elsewhere (17). Peptide patterns were stained specifically for tyrosine by the method of Acher and Crocker (18).

Ultracentrifugation. Preparative ultracentrifugation was performed in a Spinco model L ultracentrifuge with a swinging bucket rotor (SW-39) with gradients of sucrose 1 to $20 \%$ (19). In most instances, tubes were cut 1.5 and $3 \mathrm{~cm}$ from the top of the sucrose column to give three fractions.

Analytical ultracentrifugal analyses were performed in a Spinco model E ultracentrifuge equipped with Schlieren optics. Sedimentation velocity experiments were performed at $52,640 \mathrm{rpm}$ in a double-sector $12-\mathrm{mm}$ cell, with rotor temperature maintained at $20^{\circ} \mathrm{C}$. Sedimentation coefficients were corrected for the density of the buffer, but not for protein concentration, which never exceeded $1 \%$.

Weight-average molecular weights were determined by the method of Archibald as modified by Klainer and Kegeles (20). Measurements were made at short enough intervals of centrifugation to avoid any redistribution of solute. The temperature of the rotor was maintained at $20^{\circ}$ C. The Schlieren optical system was used with a phase plate at the diaphragm, which was maintained at $80^{\circ}$ to keep the curve outline sharp and to minimize the uncertainty of the curve position at the meniscus. Runs were made with a $12-\mathrm{mm}$ cell using a $2^{\circ}$ sector at 35,600 rpm. Measurements near the cell bottom were not used. The concentration of the original sample was determined in arbitrary units in a synthetic boundary cell. Photographs were made on Kodak metallographic plates. Measurements of the photographic plates were made in a Mann microcomparator.

The concentration of the protein at the meniscus $\left(C_{m}\right)$ was calculated from the measurements using the equation (20):

$$
C_{m}=C_{o}-\frac{0.01}{F X^{2}} \sum_{n=o}^{n x} X^{2} Z_{n},
$$

where $C_{0}$ is the original concentration (determined in the synthetic boundary cell); $0.1 \mathrm{~cm}$ is the comparator interval along the $X$ axis; $F$ is the enlargement factor; $Z_{n}$ is the ordinate (proportional to concentration gradient, $d c / d x)$; and $n_{x}$ is the number of comparator intervals needed to bring the ordinate to zero. The solvent correction was checked and found to be negligible.

The weight average molecular weight $\left(M_{w}\right)$ was then determined from the formula:

$$
M_{w}=\frac{R T}{(I-\bar{v} \rho) \omega^{2}} \cdot \frac{(d c / d x)_{m}}{X_{m} C_{m}},
$$

with $\omega$ the angular velocity. The partial specific volume $v$ for the urinary $\gamma$-globulin was not determined; the value accepted for serum $\boldsymbol{\gamma}$-globulin was used, $0.736 \mathrm{ml}$ per $\mathrm{g}$ Diffusion values were measured in a synthetic boundary cell. Fujita's (21) correction was not applied to the diffusion constant. 
Electrophoresis. Cellulose-acetate strips (22) were used with a borate buffer at $\mathrm{pH} 8.6(\mu$ 0.064). After drying, the strips were stained with either Ponceau $\mathrm{S}$ or Nigrosin. Starch-block electrophoresis was performed with hydrolyzed starch 7 in borate buffer at $\mathrm{pH} 8.6(\mu$ 0.064) (23). The separated proteins from serum or urine were eluted from $1-\mathrm{cm}$ segments of the blocks. Urinary protein fractions with electrophoretic mobilities corresponding to those of individual serum proteins were pooled and dialyzed against distilled water. The fractions were lyophilized, resuspended in $0.15 \mathrm{M} \mathrm{NaCl}$, and centrifuged at $15,000 \mathrm{rpm}$ for 20 minutes to remove insoluble starch granules. The processed eluates from $1-\mathrm{cm}$ segments of protein-free starch blocks contained soluble starch in quantities sufficient to appear as a peak in the Schlieren pattern upon ultracentrifugation. Consequently, a polyvinyl chloride preparation 8 to replace starch was used for the electrophoretic separation of the samples analyzed by ultracentrifugation.

Polio virus neutralization. Neutralizing antibody to polio viruses was measured ${ }^{9}$ by the immunoinactivation procedure as previously described (6).

Urinary excretion of radioiodinated proteins after iv injection of labeled $7 S \gamma_{2}$-globulins. A $\gamma$-globulin preparation (15 $\mathrm{mg}$ in $3 \mathrm{ml}$ of carbonate buffer at $\mathrm{pH} 9.2$ ) obtained as fraction II-1,2 by Cohn's method 9 was labeled with $\mathrm{I}^{131}$ as described elsewhere (24). The labeled $\gamma$ globulin was dialyzed against $10 \%$ sucrose in $0.15 \mathrm{M}$ $\mathrm{NaCl}$. The protein was then centrifuged at $35,000 \mathrm{rpm}$ for 18 hours in a gradient of sucrose (10 to $40 \%$ ) to assure ultracentrifugal homogeneity of the material to be injected. The sucrose gradient was sliced in six equal segments. The solution from each segment was assayed for radioactivity in a 3- $\times 3$-inch $\mathrm{NaI}$ crystal scintillator and for protein concentration by reading the optical density at $280 \mathrm{~m} \mu$. The middle two segments with the highest counts and optical density were combined and dialyzed against $0.15 \mathrm{M} \mathrm{NaCl}$ at $2^{\circ} \mathrm{C}$. The nondialyzable solution $(15 \mathrm{ml})$ was sterilized; $83 \mu \mathrm{c}$ of $\mathrm{I}^{131}$ was injected intravenously into a normal person and a patient known to have agammaglobulinemia.

Blood was drawn at 12 minutes, 12 hours, and 36 hours after iv administration of the iodinated $\gamma$-globulin. Total urinary output was collected for the first 12 hours and for the three 24 -hour periods thereafter. Urine samples were concentrated by pervaporation, followed by lyophilization, and a sample was separated by zone electrophoresis on starch. Materials from each $1-\mathrm{cm}$ segment of the blocks were assayed for radioactivity; protein concentration was estimated by measurement of optical density at $280 \mathrm{~m} \mu$.

\footnotetext{
${ }^{7}$ Connaught Medical Laboratories, University of Toronto, Toronto, Canada.

8 Pevikon, C-870, Stockholms Superfosfat Fabriks Aktiebolag, Stockholm, Sweden.

${ }^{9} \mathrm{By}$ Dr. A. Martin Lerner.
}

\section{RESULTS}

Fractionation of urinary proteins. A representative pattern of separation of the concentrated (lyophilized) urinary proteins by starch-block electrophoresis is shown in Figure 1. This pattern compares favorably with those obtained by movingboundary electrophoresis (25). In the present studies, however, optical densities at $280 \mathrm{~m} \mu$ may not necessarily represent true protein concentrations of the various fractions. Pigments, which are bound to urine proteins, possess a strong ultra-

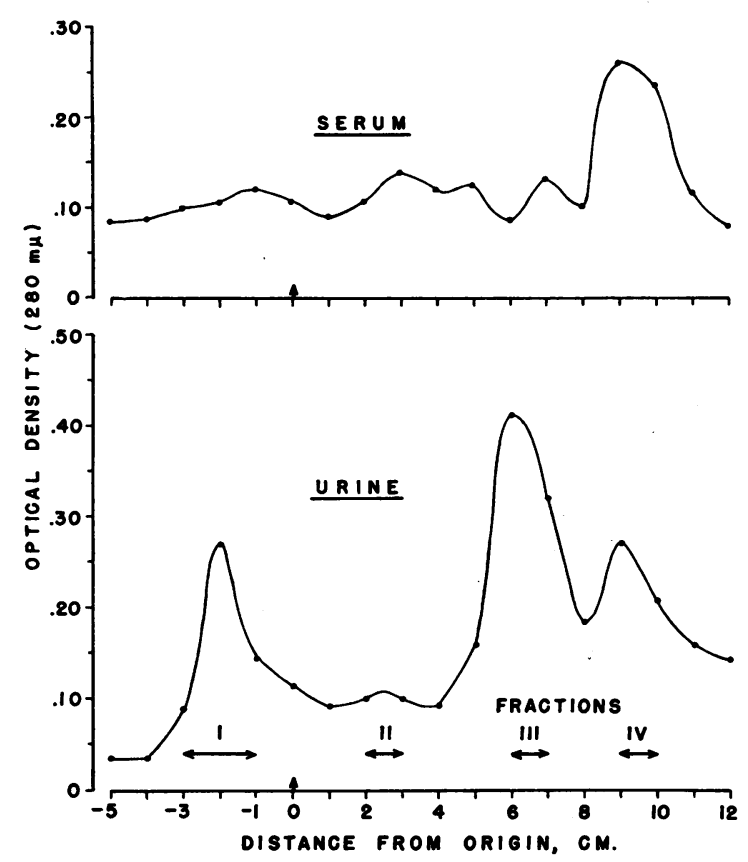

Fig. 1. Separation by STARCh-Block electrophoresis OF NORMAL HUMAN SERUM AND DIALYZED, LYOPHILIZED, NORMAL HUMAN URINE.

violet absorption and probably contribute to the optical densities observed. By double diffusion in agar gel and immunoelectrophoresis, the eluates from the area corresponding to fraction I of the starch block were shown to possess antigenic properties common to those of serum $7 \mathrm{~S} \gamma$-globulins.

Figure 2 shows the elution pattern of the urinary proteins obtained from the DEAE cellulose column, and Figure 3, the immunoelectrophoretic patterns of the fractions. The fraction eluted from the DEAE cellulose resin with $0.0175 \mathrm{M}$ phosphate buffer at $\mathrm{pH} 6.3$ contained proteins with 
the same antigenic specificities and electrophoretic mobilities as fraction I by starch-block electrophoresis. Figure 3A depicts the immunoelectrophoretic pattern obtained when an antiserum prepared against normal human serum reacted with a sample of concentrated urine proteins; the reaction of this antiserum with normal human serum is also shown. At least five precipitin lines, corresponding to five, electrophoretically distinguishable proteins of urine with antigenic sites similar to those of serum, are evident. Figure 3B shows the precipitin lines obtained with fraction I (prepared by chromatography on DEAE cellulose) of the same urine. Two lines are visible (one of them very faintly), both with a mobility similar to that of serum $\gamma$-globulins, but appearing to migrate toward the anode at a faster rate. $\gamma$-Globulins were not confined to fraction I, but were eluted also in fractions II and III (Figure 3C, D), although in these two fractions they possessed either an atypical $\gamma$ mobility, or they were contaminated with other urinary proteins. The immunoelectrophoretic patterns of fractions IV, V, and VI (Figure 2) are depicted in Figure 3E, F, and G, respectively.
Electrophoretic patterns of urine concentrated by lyophilization and of normal serum with cellulose-acetate strips are shown in Figure 4. In a number of instances, separation of urinary proteins by cellulose-acetate or starch-gel electrophoresis revealed a component that migrated further toward the cathode than did serum $\gamma$-globulins (arrow in Figure 4B). A precipitin line did not result from the reaction of this slow-moving component with antisera prepared in rabbits against serum $7 \mathrm{~S} \gamma_{2}$-globulins.

Ultracentrifugal analyses were performed on eleven urines of seven persons. Figure 5A shows a representative Schlieren diagram obtained with concentrated whole urine. $S_{w, 20}$ was $1.3 \pm 0.1$, significantly lower than the value of Webb and associates (2), and it did not vary significantly whether the urine samples were concentrated by lyophilization, by dialysis and pervaporation, or with Sephadex.

Although ultracentrifugal patterns of total urine concentrates failed to reveal components with $S_{w, 20}$ over 2 , the concentrated $\gamma$-globulins from the same urines usually contained both a major component with an average $S_{w, 20}$ of $1.5 \pm 0.3$ and a minor

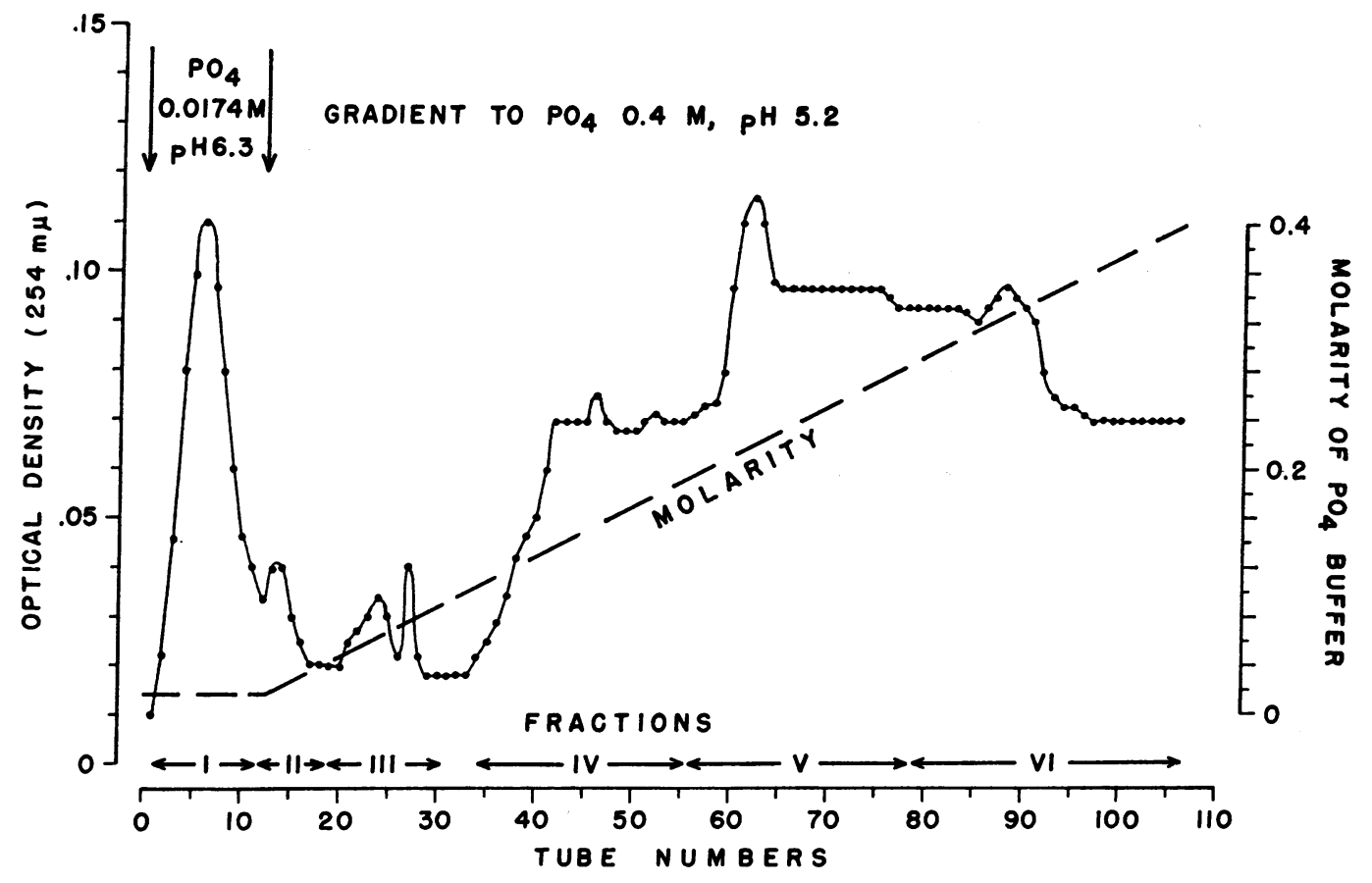

Fig. 2. Separation by DEAE cellulose chromatography of Lyophilized NORMal HUMAN URINE. 

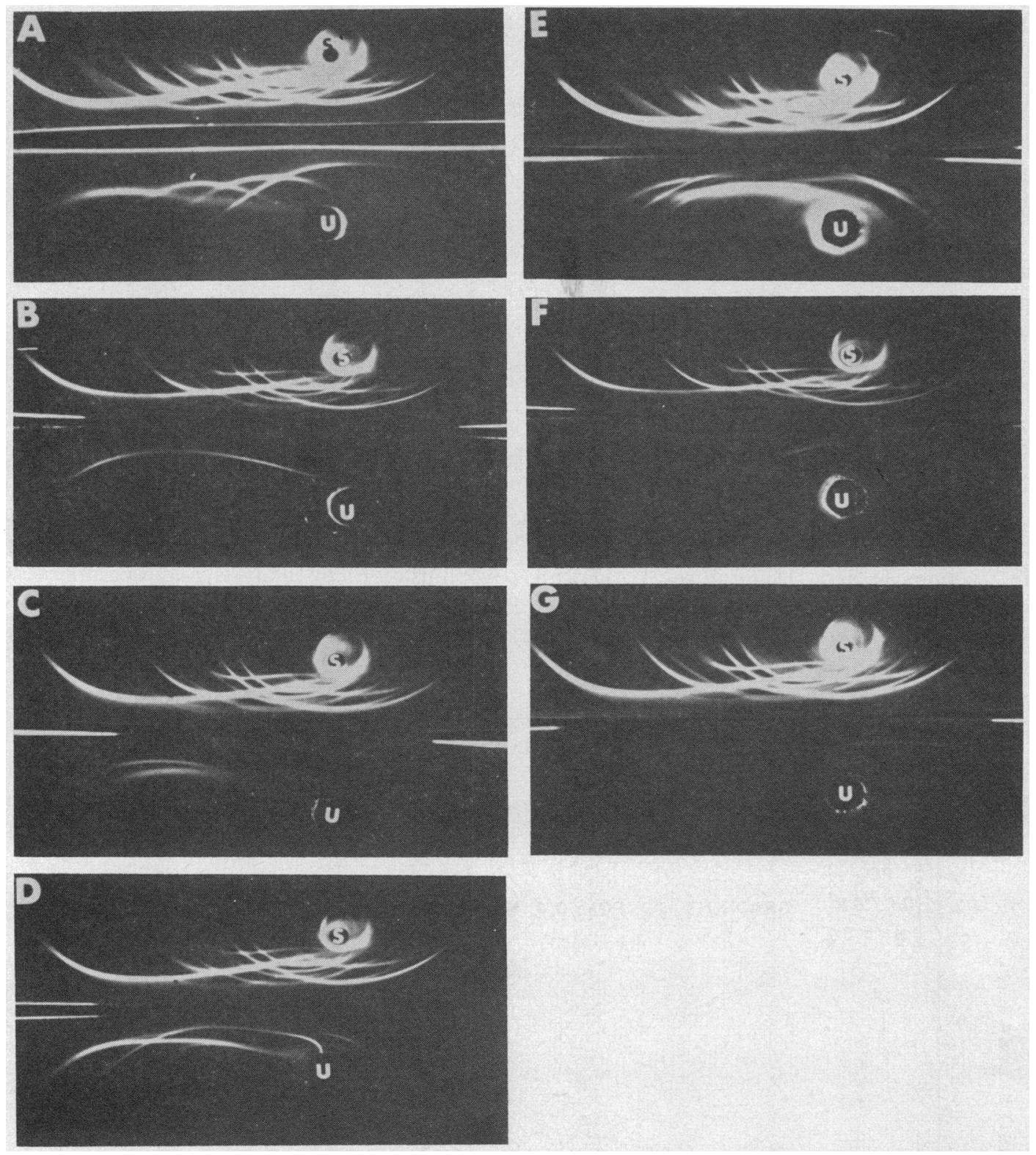

Fig. 3. IMmunoelectrophoResis OF Chromatographic (DEAE) FRACTIONS OF NORMAL hUMAN URINE. (See Figure 2.) $s=$ Normal human serum, $u=$ normal human urine. Center well contained horse antinormal human serum. A, lyophilized normal human urine; B, fraction I; C, fraction II ; D, fraction III ; E, fraction IV, F, fraction V; and G, fraction VI.

one with an average $S_{w, 20}$ of $5.7 \pm 0.5$ (Figure 5B). These values represent the arithmetic means of the sedimentation coefficients of urinary $\gamma$-globulins from each of five persons. In all instances, the major $1.5 \mathrm{~S}$ peak was broad. Even after prolonged centrifugation, complete separation of this peak from the meniscus was not enough to indicate the distribution of molecular weights in the system.

Centrifugation in a sucrose gradient was used to separate the two differently sedimenting components of urine $\gamma$-globulins. Materials from the top and bottom fractions of the sucrose gradients were analyzed by sedimentation velocity for mo- 


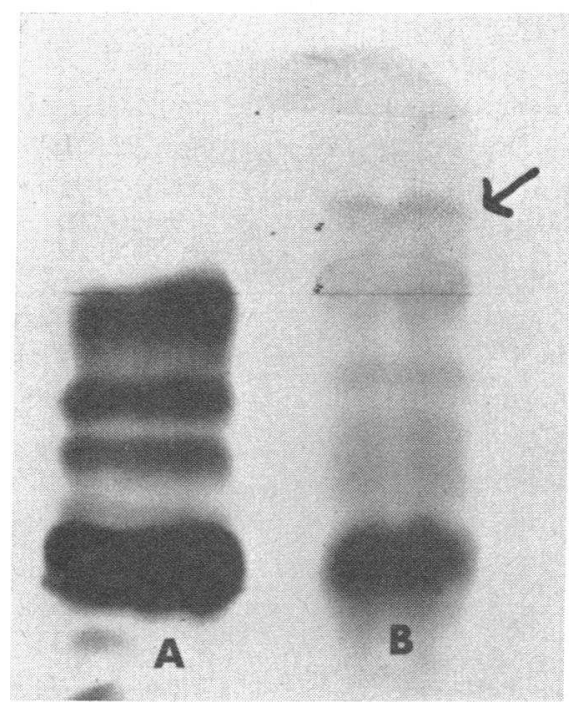

Fig. 4. Separation by cellulose-Acetate electroPHORESIS OF A) NORMAL HUMAN SERUM AND B) DIALYZED AND LYOPHILIZED hUMAN URINe. Arrow points at urinary components migrating toward cathode faster than $\gamma$-globulin.

lecular size, and by immunoelectrophoresis and double diffusion in agar for antigenic properties. Ultracentrifugation of the top fraction revealed only low-molecular-weight material with an $\mathrm{S}_{\mathrm{w}, 20}$ of 0.92 (Figure $5 \mathrm{C}$ ).

Ultracentrifugation of the $\gamma$-globulins from the bottom fractions of the sucrose gradients showed a single peak with an $S_{w, 20}$ of 7.1. These large $\gamma$-globulins were present in all but two of the bot- tom fractions of the urine concentrates tested from twelve different persons. The finding of a largemolecular-weight material in this protein fraction of normal urine differs from that of Webb and associates (2) and Rowe and Soothill (4), but corresponds to that of Franklin (3).

Figure 6 shows the precipitin lines obtained when the top and bottom fractions of two preparations of urinary $\gamma$-globulins separated in sucrose gradients reacted in agar with an antiserum prepared in rabbits against human serum $7 \mathrm{~S} \gamma_{2}$-globulins. The material from the top fraction gave a reaction of partial identity with serum $7 \mathrm{~S} \gamma$-globulins (Figure 6, left). The bottom fraction of one preparation contained a single component that gave a reaction of complete identity with serum $\gamma$-globulins (Figure 6, left), whereas in another bottom fraction, (Figure 6, right) there were three lines suggesting either that the faster sedimenting component was not antigenically homogenous, or that the low-molecular-weight component of urine $\gamma$-globulins was polydisperse; complete separation was not obtained in this preparation.

Results by the Ouchterlony method suggested that the two precipitin lines visible in the immunoelectrophoretic pattern of the urinary $\gamma$-globulins (Figure 3B) might correspond to the two differently sedimenting components. This suggestion was confirmed by immunoelectrophoresis; the top fraction from the gradient formed a pre-

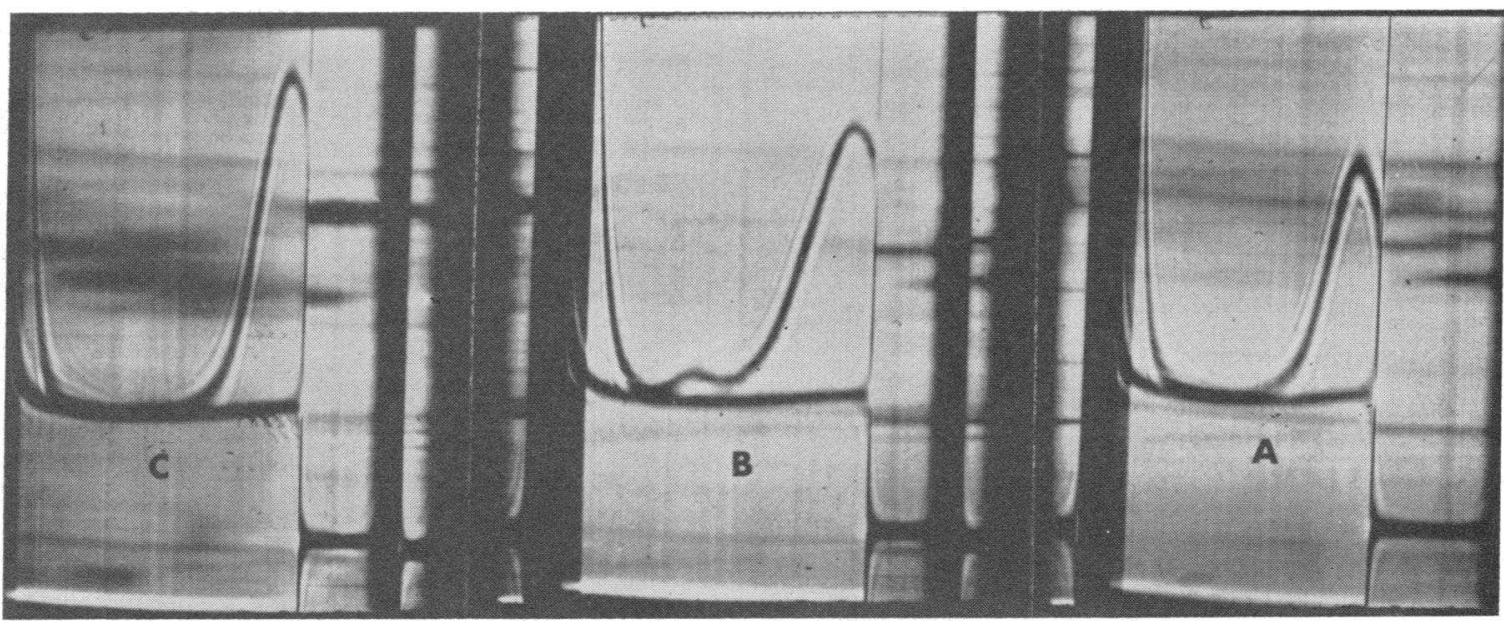

Fig. 5. Ultracentrifuge patterns of A) total concentrated urine, B) Urinary $\gamma$-globulins (DEAE), and C) TOP OF SUCROSE GRADIENT. 


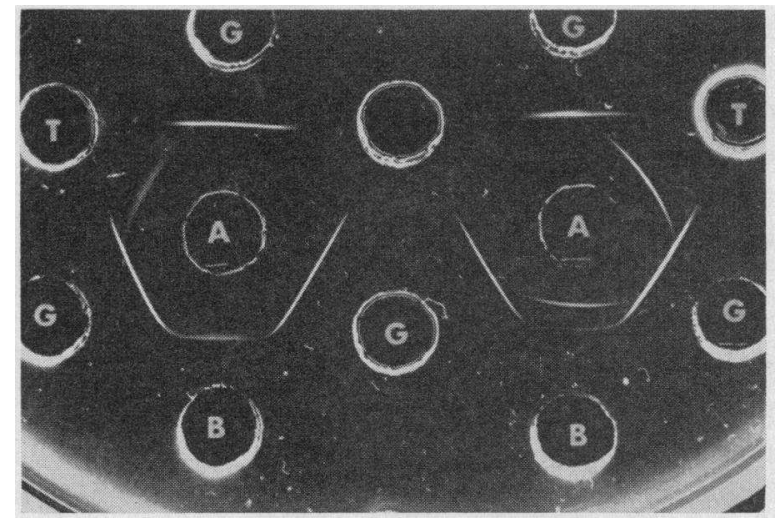

Fig. 6. DoUble DIFFUSION IN AGAR. G= human serum $7 \mathrm{~S} \gamma$-globulin, $\mathrm{A}=$ rabbit antihuman $7 \mathrm{~S} \gamma$-globulin, $\mathrm{T}$ $=$ urine fraction from top of sucrose gradient, and $\mathrm{B}$ $=$ urine fraction from bottom of sucrose gradient.

cipitin line corresponding to the line closest to the antibody well, and the bottom fraction, to the one farthest from it (Figure 3B). Although this bottom fraction constituted only $10 \%$ or less of the total urinary $\gamma$-globulins (8), it formed a much clearer precipitin line with the antibody than did the low-molecular-weight material.

Antibody activity. Concentrates of urine had been shown to contain neutralizing activity against poliovirus types I and III (6). It was therefore of interest to determine if this activity were associated with the $7 \mathrm{~S}$ fraction or the low-molecularweight material in these urines. The urine proteins were separated in fractions by starch-block electrophoresis and cellulose chromatography. Analysis by double diffusion in agar of fraction I (DEAE) and of materials eluted from the starch blocks with an electrophoretic mobility matching that of serum $7 \mathrm{~S} \gamma$-globulin indicated that only materials giving reactions of partial identity with $7 \mathrm{~S} \gamma$-globulin were present in these urines. The precipitation lines corresponded to those obtained from the upper fractions of the separation by sucrose gradient. In the ultracentrifuge, fraction I from these urines gave only one peak with an $S_{w, 20}$ of 1.70 and did not contain the minor, $7.1 \mathrm{~S}$ component ordinarily found in concentrated urinary $\gamma$-globulins. Virus-neutralizing activity resided in fraction I (DEAE) of these urines and was found only in urines from subjects with neutralizing activity in the corresponding serum. In some instances, antibody could be demonstrated in the urine only a week or more after booster doses of vaccine and only after the antibody titer in the serum had increased. No comparison of titers obtained with urine $\gamma$-globulins with those of the corresponding sera has been attempted.

Precipitating antibodies to tetanus toxoid were demonstrated in subjects' urines after booster doses of that antigen. The activity of these antibodies was also associated with the low-molecular-weight component of the $\gamma$-globulins from the top segment of the sucrose gradients. The $\gamma$-globulins containing these antibodies were shown by double diffusion in agar to give a single precipitin line that showed a reaction of partial identity with serum $7 \mathrm{~S} \gamma$-globulin (Figure 6, A-T). The faster sedimenting component, from the bottom segment, did not precipitate with the antigen, perhaps owing to its low concentration in the urine. The precipitin lines from the reaction of serum and the urinary low-molecular-weight $\gamma$-globulins with tetanus toxoid in Preer tubes are shown in Figure 7. Precipitation of the serum antibodies with homologous antigen occurred within 4 to 7 days, whereas precipitin lines with the $\gamma$-globulins of urine took up to 3 or 4 weeks to appear. Precipitin lines could not be demonstrated with these low-molecular-weight urinary $\gamma$-globulins when they reacted in agar with diphtheria toxoid, type-specific pneumococcal polysaccharides, normal human serum, or $0.15 \mathrm{M} \mathrm{NaCl}$. $\gamma$-Globulins prepared from the urines of persons whose sera did not precipitate with tetanus toxoid did not react visibly with that antigen.

The material from the top segment of the sucrose gradient that precipitated with tetanus toxoid had a molecular weight of 12,900 which decreased with time, indicating the polydisperse nature of these preparations (Table I). The diffusion constant was $7.4 \times 10^{-7}$ as compared to $4.0 \times 10^{-7}$

TABLE I

Archibald measurements of molecular weights as a function of time for $S_{w, 20}$ of 0.92 urinary $\gamma$-globulin

\begin{tabular}{rrrr}
\hline Time & $\Sigma_{n} Z_{n} X_{n}{ }^{2}$ & $C_{m}$ & $M_{w}$ \\
\hline $\min$ & & & \\
1 & 68.936 & 0.0266 & 13,104 \\
6 & 83.318 & 0.0249 & 12,437 \\
10 & 93.144 & 0.0237 & 12,143 \\
14 & 102.118 & 0.0226 & 11,670 \\
26 & 120.515 & 0.0204 & 10,749 \\
30 & 115.081 & 0.0211 & 10,420 \\
\hline
\end{tabular}

Average $C_{0}=0.0349$. 

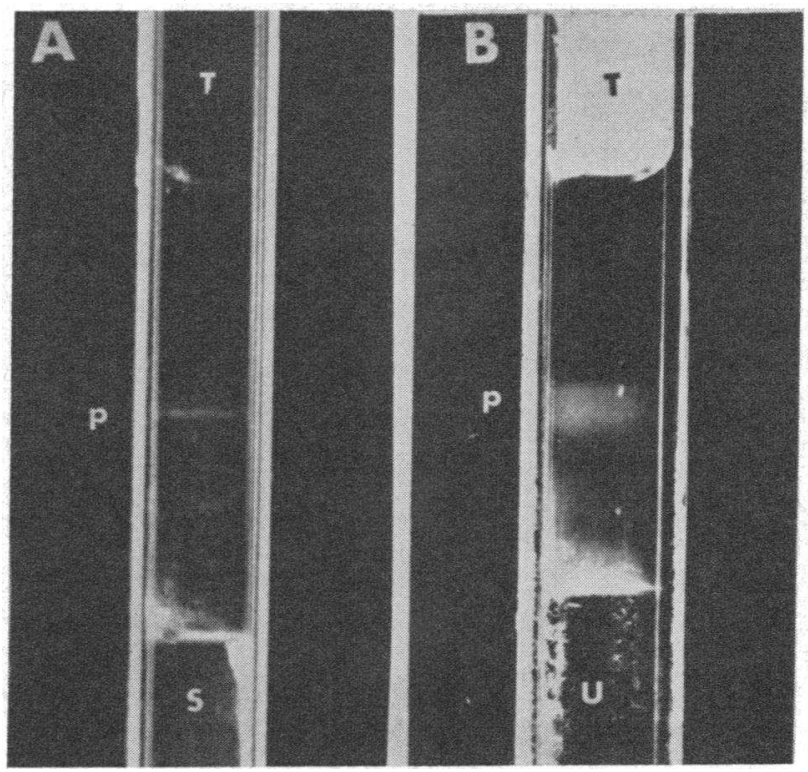

Fig. 7. Double diffusion in agar (tubes). $p=$ Precipitin lines, $t=$ tetanus toxoid, $s=$ human antitetanus serum, and $\mathfrak{u}=$ low-molecular-weight urinary $\boldsymbol{\gamma}$-globulin.

for serum $7 \mathrm{~S} \gamma$-globulins (26). $S_{w, 20}$ was 0.92 . $\mathrm{S}$ successively increased for materials from areas of increasing sucrose concentration.

Sedimentation coefficients of the total urinary $\gamma$-globulins from the various fractions from the separation by sucrose gradient were nearly constant in different experiments at the concentrations used $(0.5$ to $1 \mathrm{~g}$ per $100 \mathrm{ml})$; measurements at lower concentrations indicated that dependence on concentration was small for a $1 \%$ change in the concentration of protein. Values for molecular weight obtained by extrapolation to infinite dilution should therefore not differ greatly from those obtained at the concentration used in these experiments.

Quantitation of urinary $\gamma$-globulins. In fraction I (DEAE) this was done by titrating increasing dilutions of a known weight of this material and of a standard solution of human $7 \mathrm{~S} \gamma$-globulin by gel diffusion in an Ouchterlony plate against a standard solution of the anti-7 $\mathrm{S} \gamma$-globulin antiserum (14). With the greatest dilution of antigen (serum $7 \mathrm{~S} \gamma$-globulin or urinary $\gamma$-globulin) that gave a visible precipitin line with antiserum as an endpoint, such lines were not discernible with less than $1.5 \mu \mathrm{g}$ of urinary $\gamma$-globulins or $0.78 \mu \mathrm{g}$ of serum $7 \mathrm{~S} \gamma$-globulin. The extinction coeffi- cient of total urinary $\gamma$-globulins $\mathrm{E}_{1 \mathrm{~cm}}^{1 \%}$ was 4.47 as compared to 14.9 for serum $\gamma_{2}$-globulins.

Analysis of peptides released by enzymatic hydrolysis of serum and urinary $\gamma$-globulins. The peptides obtained from enzymatic digestion of heat-denatured (HD) total urinary $\gamma$-globulins and of the HD $\gamma$-globulins of $0.92 \mathrm{~S}$ were compared with those from HD serum $7 \mathrm{~S} \gamma$-globulins. When trypsin hydrolysates were adjusted, after digestion, to $\mathrm{pH} 4.2$, about $15 \%$ of the weight of $7 \mathrm{~S} \gamma$-globulin precipitated, whereas little or no

TABLE II

Relation between the number of micromoles $\mathrm{NaOH}$ per micromole protein used during enzymatic digestion and the number of peptides revealed

\begin{tabular}{ccc}
\hline \multicolumn{1}{c}{ Sample* } & $\begin{array}{c}\mu \text { Moles } \\
\text { OH } \\
\mu \text { mole } \\
\text { protein }\end{array}$ & $\begin{array}{c}\text { No. of } \\
\text { peptides }\end{array}$ \\
\hline Serum $\gamma$-globulin (HD) & 67 & 55 \\
DEAE fraction I (HD) $\dagger$ & 5.4 & 32 \\
Segment 1 of fraction I (HD) $†$ & 5.2 & 11 \\
Serum $\gamma$-globulin (PAO) & 130 & 70 \\
DEAE fraction I (PAO) $\dagger$ & 7.3 & 30 \\
\hline
\end{tabular}

${ }^{*} \mathrm{HD}=$ heat-denatured $; \quad \mathrm{PAO}=$ performic-acid oxidized.

$\dagger$ An average mol wt of 30,000 was assumed for this fraction of the urinary $\gamma$-globulins.

$\pm S_{w, 20}=0.92$. 
protein precipitated from the urinary $\gamma$-globulin. Some of the peptides in the patterns of urinary $\gamma$-globulins appeared to be present in those of serum $7 \mathrm{~S} \gamma$-globulins. Most of the peptides of the urinary $\gamma$-globulins, however, did not overlap those of serum $\gamma$-globulins. More peptides were distinguishable in patterns of the serum $7 \mathrm{~S} \gamma$-globulins than in those of the total urinary $\gamma$-globulins. Only eleven peptides were distinguishable in hydrolysates of the $0.92 \mathrm{~S}$ urinary $\gamma$-globulins.

In contrast to the results obtained with serum $7 \mathrm{~S} \gamma$-globulins, the number of spots evident on the chromatograms of urinary $\gamma$-globulins was greater than the number of moles of hydroxyl ions needed per mole of urinary proteins during enzymic digestion to keep the $\mathrm{pH}$ constant at 8.0 (Table II).
The peptides obtained from enzymatic digestion of performic-acid-oxidized (PAO) total urinary $\gamma$-globulins were compared with those from $\mathrm{PAO}$ serum $7 \mathrm{~S} \gamma$-globulins. Fewer peptides were noted on the patterns of PAO urinary $\gamma$-globulins than those obtained with the serum $7 \mathrm{~S} \gamma$-globulins (Table II). As observed with HD $\gamma$-globulin, only a few peptides from the PAO urinary $\gamma$-globulin were superimposable on those from serum $7 \mathrm{~S} \gamma$-globulins. Performic-acid oxidation of the urinary $\gamma$-globulins before enzymatic digestion resulted in a peptide pattern with only two fewer spots than that obtained by enzymatic digestion of HD urinary $\gamma$-globulins. Considerably fewer tyrosine residues were found in the peptide patterns of urinary $\gamma$-globulins as compared to those of serum $\gamma_{2}$-globulins.

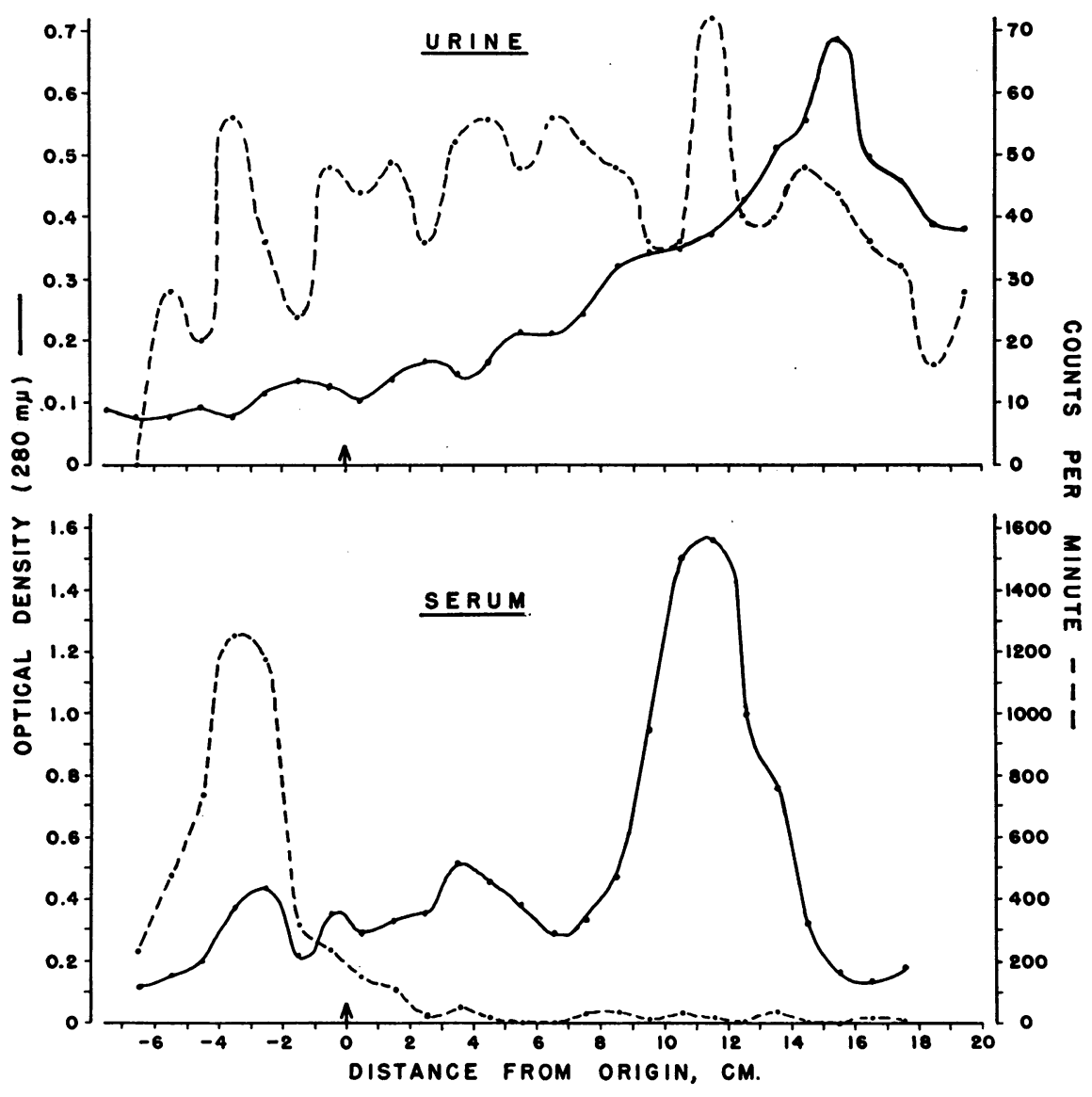

Fig. 8. Separation by STARCh-Block ElectrophoResis of NORMAL hUMAN SERUM AND PERVAPORATED, LYOPHILIZED NORMAL huMAN URINE. Solid line: optical density at $280 \mathrm{~m} \mu$. Dotted line: counts per minute corrected for background and decay. 
TABLE III

Activity of urinary proteins after injection of $I^{131}$-labeled serum $7 S \gamma$-globulins

\begin{tabular}{|c|c|c|c|c|c|}
\hline \multirow[b]{2}{*}{ Subject } & \multirow[b]{2}{*}{$\begin{array}{l}\text { Time of urine } \\
\text { collection (after } \\
\text { injection) }\end{array}$} & \multicolumn{3}{|c|}{ Activity* } & \\
\hline & & Total† & $\gamma$-Globulins & $\begin{array}{l}\% \text { in } \gamma- \\
\text { globulins }\end{array}$ & \\
\hline & hours & $c p m$ & $c p m$ & $\%$ & \\
\hline Normal & $\begin{array}{r}0-12 \\
12-36 \\
36-60 \\
60-84\end{array}$ & $\begin{array}{r}471 \\
62 \\
244 \\
349\end{array}$ & $\begin{array}{r}166 \\
25 \\
94 \\
184\end{array}$ & $\begin{array}{l}35 \\
40 \\
39 \\
53\end{array}$ & $\therefore$ \\
\hline Agammaglobulinemic $\ddagger$ & $\begin{array}{r}0-12 \\
12-36 \\
36-60 \\
60-84\end{array}$ & $\begin{array}{r}308 \\
139 \\
85 \\
198\end{array}$ & $\begin{array}{r}192 \\
82 \\
58 \\
119\end{array}$ & $\begin{array}{l}62 \\
59 \\
68 \\
60\end{array}$ & \\
\hline
\end{tabular}

* Corrected for background and radioactive decay.

† Total counts per minute recovered from all fractions of the starch block; recovery of $I^{131}$ from amount applied ranged from 95 to $98 \%$. Varying amounts of urine concentrates from the time intervals described were placed on the blocks.

$\ddagger$ White man 18 years old with congenital agammaglobulinemia. At the time of this study, serum $\gamma$-globulin was less than $100 \mathrm{mg}$ per $100 \mathrm{ml}$.

Reduction of urinary $\gamma$-globulins. ${ }^{10}$ A preparation of urinary $\gamma$-globulins from the top of a separation by sucrose gradient had an apparent molecular weight $\mathrm{M}_{\mathbf{w}}$ of 9,800 . These proteins were reduced under mild conditions with mercaptoethanol to determine if easily accessible disulfide groups were indeed present in these $\gamma$-globulins. Reductions were done in $0.02 \mathrm{M}$ mercaptoethanol at $\mathrm{pH}$ 8.0. Samples were kept at $2^{\circ} \mathrm{C}$ for various periods, but never less than 24 hours. From the approach to equilibrium during sedimentation as an estimation of molecular weight after reduction, these urinary $\gamma$-globulins had a $\mathrm{M}_{\mathrm{w}}$ of 6,200 .

Urinary excretion of radioiodinated proteins after iv injection of labeled $7 S \gamma_{2}$-globulins. A representative pattern of the starch-block electrophoresis of concentrated urinary proteins from a normal person given $\mathrm{I}^{131}$-labeled $7 \mathrm{~S} \gamma_{2}$-globulins is shown in Figure 8. The urine was concentrated by pervaporation followed by lyophilization. This pattern differed markedly from that obtained when the urine was concentrated by lyophilization alone (Figure 1). Approximately one-third to one-half of the protein-bound radioactivity in the normal urine was present in proteins with the electrophoretic mobility of $\gamma$-globulin (Table III).

${ }_{10}$ This study was performed in collaboration with Dr. Karl Schmid of the Massachusetts General Hospital, Boston, Mass., who kindly determined the molecular weights.
More than $50 \%$ of the protein-bound radioactivity was found in similar $\gamma$-globulin areas of starch blocks of the urinary proteins from the patient with agammaglobulinemia.

$\mathrm{NaI}^{131}$ in $\mathrm{Na}_{2} \mathrm{SO}_{3}$ was added to two urine samples, in one instance before and in the other after concentration by pervaporation. After dialysis to remove free iodide, the urines were submitted to starch-block electrophoresis. Binding of the radioactive atoms to urinary proteins was limited to materials possessing the electrophoretic mobilities and immunologic specificity of serum $\beta$-globulins and albumin.

In a separate experiment, concentrated urine from the normal person was applied to a column of DEAE cellulose, and materials eluted by $0.0175 \mathrm{M}$ phosphate buffer at $\mathrm{pH} 6.3$ (fraction I) were concentrated and separated in a gradient of sucrose (1 to 20\%). A comparable amount of radioactivity was found in the top and bottom fractions of the gradient; a larger amount of radioactivity was found in the middle fraction. The protein concentration, as determined by dry weight, was greatest at the top of the gradient and decreased toward regions of higher sucrose concentration.

\section{DISCUSSION}

The present study describes certain of the physiochemical and immunochemical properties of the 
low-molecular-weight $\gamma$-globulins present in normal human urine that possess both precipitating and viral neutralizing antibody activity. These $\gamma$-globulins at $\mathrm{pH} 8.6$ are more electronegative than normal serum $7 \mathrm{~S} \gamma$-globulins and share certain antigenic determinants with serum $7 \mathrm{~S} \gamma$-globulins.

Urinary $\gamma$-globulins from individuals hyperimmunized with purified tetanus toxoid precipitated specifically with that antigen. The reason precipitation took longer when tetanus toxoid reacted with the low-molecular-weight $\gamma$-globulins of urine, compared with the time for the same antigen to precipitate with serum antibody is not clear. The physicochemical factors for precipitation with these low-molecular-weight antibodies may differ from those required for $7 \mathrm{~S} \gamma$-globulins. Because the yield of low-molecular-weight $\gamma$-globulins from large volumes of urine was relatively small, precipitation in agar gels had to be used rather than quantitative precipitation from solutions; the agar matrix may have been necessary for visible precipitation. That precipitation of antigen with lowmolecular-weight $\gamma$-globulin from the top of a sucrose gradient was not due to coprecipitation with contaminating urinary $7 \mathrm{~S} \gamma$-globulins was shown by the inability of the concentrated $7 \mathrm{~S}$ $\gamma$-globulins from the bottom of the same sucrose gradient to form a visible precipitate with the tetanus toxoid. Moreover, material from the top of separations by sucrose gradient of whole human antiserum centrifuged in parallel with the urine did not precipitate with the antigen, whereas the bottom fractions did.

Titration by immunoprecipitation (14) indicated that about $50 \%$ of the urinary $\gamma$-globulins reacted with the antiserum and thus had antigenic sites common to serum $7 \mathrm{~S} \gamma$-globulins. Separation by starch-block electrophoresis of the urinary proteins of a patient with agammaglobulinemia revealed patterns indistinguishable from those of normal subjects; however, materials eluted from the starch blocks of this patient that corresponded to the area of electrophoretic mobility of serum $\gamma$-globulins did not react with an antiserum against serum $7 \mathrm{~S} \gamma$-globulins.

The low value for the extinction coefficient of the urinary $\gamma$-globulins suggests that either these proteins are poor in aromatic amino acid residues, or they contain proteins poor in tyrosine and tryptophane. The low number of tyrosine residues in the pattern of peptides after enzymatic digestion of these proteins favors the first possibility but does not exclude the second.

In pepticle patterns of fraction I (DEAE) and in patterns for the protein of the top of separations by sucrose gradient of fraction I, only a few of the peptides had a mobility similar to that of peptides released by enzymatic digestion of serum $7 \mathrm{~S} \gamma$-globulins. Similarly, the mobility of the majority of peptides obtained after enzymatic digestion of PAO urinary $\gamma$-globulins differed from that of peptides from PAO serum $\gamma_{2}$-globulins. These results suggest the possibility that the primary structure of urinary $\gamma$-globulins may differ in portions from that of serum $7 \mathrm{~S} \gamma_{2}$-globulins; hence, at least part of the urinary $\gamma$-globulins may not be derived from the $7 \mathrm{~S}$ serum $\gamma_{2}$-globulins. The results of studies of the excretion of $\mathrm{I}^{131}$-labeled $\gamma$-globulin reported by Webb, Rose, and Sehon (2) and Franklin (3) were interpreted by these authors as showing that urinary $\gamma$-globulins are derived, at least in part, from serum $7 \mathrm{~S}$ $\gamma$-globulins. They reported a significantly greater, relative amount of radioactivity in the urinary $\gamma$-globulins than was found in the present study; the reason for this discrepancy is not clear. The long half-life of serum $\gamma$-globulins and their high concentration in serum compared to that in urine make it difficult to interpret the results obtained with labeled $\gamma$-globulins. Since proteins containing radioactive iodine were found in almost all sections of the starch-block fractionation of urine in this study, it is possible that the degradation of the iodinated, isologous, serum $7 \mathrm{~S} \gamma$-globulins either released iodide that was then bound to proteins unrelated to $\gamma$-globulins, or yielded fragments with different electrophoretic mobilities. The first possibility is unlikely, since control experiments showed that adsorption of iodide by urinary proteins is not random but preferential; the second possibility cannot be ascertained with the present data. The reason for the higher percentage of counts found in the proteins with a mobility similar to that of serum $\gamma$-globulins in the urine of the agammaglobulinemic patient compared to that of the normal volunteer is not clear, but agrees with the immunochemical evidence that the urinary $\gamma$-globulins are not homogeneous and may have multiple origins. 
The lack of relation between the amount of radioactivity and the protein concentration in the different sucrose-gradient fractions of the urinary $\gamma$-globulins from the normal individual may be related to the results found by analyses of peptides, which suggested that the relative tyrosine content of the urinary $\gamma$-globulins may vary with the molecular weight of the protein. These results appear to differ from those of Stevenson (27), who may, however, have been dealing with a different group of urinary $\gamma$-globulins.

The low-molecular-weight $\gamma$-globulins of urine may be derived in whole or in part from the lowmolecular-weight $\gamma$-globulins described in normal human serum by Berggard (28). The origin of the low-molecular-weight $\gamma$-globulins of serum is not known. It is possible that low-molecularweight $\gamma$-globulins of serum are normally produced independently of the $7 \mathrm{~S} \gamma$-globulins and, owing to their small size, are cleared rapidly by the kidney. ${ }^{11}$

\section{SUM MARY}

Urines from persons immunized with tetanus toxoid or poliovirus vaccine were shown to contain low-molecular-weight antibodies specific for the immunizing antigens. Neutralizing activity to poliovirus was found in $\gamma$-globulins with an $\mathrm{S}_{\mathrm{w}, 20}$ of 1.7. Precipitating antibody activity against tetanus toxoid was found in proteins with a molecular weight of 12,900 and an $S_{w, 20}$ of 0.92 .

The peptide patterns after tryptic digestion of urinary $\gamma$-globulins differed from those after tryptic digestion of serum $7 \mathrm{~S} \gamma$-globulins. Immunochemical and isotopic studies indicated that the low-molecular-weight $\gamma$-globulins are heterogeneous and may have multiple origins.

\section{REFERENCES}

1. Merler, E., J. S. Remington, D. Gitlin, and M. Finland. Enzymatic hydrolysis of low molecular weight antibodies from normal human urine. Fed. Proc. 1962, 21, 21.

11 Recent separation of low-molecular-weight urinary $\gamma$-globulins on columns of Sephadex G-75 resin from the components of higher molecular weight supports assumption of the value of $v$ used in the determination of molecular weight and indicates that the value reported here may be indeed correct, and not apparently faulty because of the presence of lipoproteins.
2. Webb, T., B. Rose, and A. H. Sehon. Biocolloids in normal human urine. II. Physiochemical and immunochemical characteristics. Canad. J. Biochem. 1958, 36, 1167.

3. Franklin, E. C. Physiochemical and immunologic studies of gamma globulins of normal human urine. J. clin. Invest. 1959, 38, 2159.

4. Rowe, D. S., and J. F. Soothill. Serum proteins in normal urine. Clin. Sci. 1961, 21, 75.

5. Remington, J. S., and M. Finland. Precipitating antibody in normal human urine. Proc. Soc. exp. Biol. (N. Y.) 1961, 107, 765.

6. Lerner, A. M., J. S. Remington, and M. Finland. Neutralizing antibody to polioviruses in normal human urine. J. clin. Invest. 1962, 41, 805.

7. Porter, R. R. The hydrolysis of rabbit $\gamma$-globulin and antibodies with crystalline papain. Biochem. J. 1959, 73, 119.

8. Remington, J. S., E. Merler, A. M. Lerner, D. Gitlin, and M. Finland. Antibodies of low molecular weight in normal human urine. Nature (Lond.) 1962, 194, 407.

9. Flodin, P., B. Gelotte, and J. Porath. A method for concentrating solutes of high molecular weight. Nature (Lond.) 1960, 188, 493.

10. Shapiro, J. High-rate laboratory filtration with Büchner funnels. Science 1961, 133, 1828.

11. Scheidegger, J. J. Une micro-méthode de l'immuno electrophorèse. Int. Arch. Allergy 1955, 7, 103.

12. Ouchterlony, O. Antigen antibody reactions in gels. IV. Types of reactions in coordinated systems of diffusion. Acta path. microbiol. scand. 1953, 32, 231.

13. Preer, J. R., Jr. A quantitative study of a technique of double diffusion in agar. J. Immunol. 1956, 77, 52.

14. Feinberg, J. G. Identification, discrimination and quantification in Ouchterlony gel plates. Int. Arch. Allergy 1957, 11, 129.

15. Hirs, C. H. W. The oxidation of ribonuclease with performic acid. J. biol. Chem. 1956, 219, 611.

16. Jacobsen, C. F., J. Léonis, K. Linderstrøm-Lang, and M. Ottesen. The pH-stat and its use in biochemistry. Methods biochem. Anal. 1957, 4, 171.

17. Gitlin, D., and E. Merler. A comparison of the peptides released from related rabbit antibodies by enzymatic hydrolysis. J. exp. Med. 1961, 114, 217.

18. Acher, R., and C. Crocker. Réactions colorées spécifiques de l'arginine et de la tyrosine réalisées après chromatographie sur papier. Biochim biophys. Acta (Amst.) 1952, 9, 704.

19. Edelman, G. M., H. G. Kunkel, and E. C. Franklin. Interaction of the rheumatoid factor with antigen-antibody complexes and aggregated gamma globulin. J. exp. Med. 1958, 108, 105.

20. Klainer, S. M., and G. Kegeles. Simultaneous determinations of molecular weights and sedimentation constants. J. phys. Chem. 1955, 59, 952. 
21. Fujita, H. Effects of a concentration dependence of the sedimentation coefficient in velocity ultracentrifugation. J. Chem. Phys. 1956, 24, 1084.

22. Kohn, J. A micro-electrophoretic method. Nature (Lond.) 1958, 181, 839.

23. Kunkel, H. G. Zone electrophoresis in Methods of Biochemical Analysis, D. Glick, Ed. New York, Interscience, 1954, vol. 1, p. 141.

24. Gitlin, D., C. A. Janeway, and L. E. Farr. Studies on the metabolism of plasma proteins in the nephrotic syndrome. I. Albumin $\gamma$-globulin and iron-binding globulin. J. clin. Invest. 1956, 35, 44.
25. Rigas, D. A., and C. G. Heller. The amount and nature of urinary proteins in normal human subjects. J. clin. Invest. 1951, 30, 853.

26. Pedersen, K. O., in Ultracentrifugal Studies of Serum and Serum Fractions, K. O. Pedersen, Ed. Uppsala, Almquist \& Viksells, 1945, p. 172.

27. Stevenson, G. T. Further studies of the gamma-related proteins of normal urine. J. clin. Invest. 1962, 41, 1190.

28. Berggard, I. On a $\gamma$-globulin of low molecular weight in normal human plasma and urine. Clin. chim. Acta 1961, 6, 545. 